\title{
The use of the Gunning Fog Index to evaluate the readability of Polish and English drug leaflets in the context of Health Literacy challenges in Medical Linguistics: An exploratory study
}

\author{
Damian Świeczkowski ${ }^{1}$, Sławomir Kułacz ${ }^{2}$ \\ ${ }^{1}$ First Department of Cardiology, Medical University of Gdansk, Poland \\ ${ }^{2}$ The WSB University in Gdansk, Poland
}

To achieve more satisfactory outcomes, healthcare providers need to communicate with the patients effectively, mainly in terms of language used between both parties [1]. Numerous studies have revealed that medical jargon may be highly incomprehensible for patients, and the lesseducated and marginalized groups are particularly sensitive to this kind of communication [2]. The language used in patient materials includes difficult terms which cannot be easily understood without a formal education and this may be the reason why drug leaflets - the primary source of drug-related information for most patients - are considered unfriendly for their users [3]. Low readability of drug leaflets is associated with poorer patient adherence to recommended therapy; thus, it can have a significant impact on achieved outcomes, and the rate of therapeutic success, particularly in chronic diseases [4]. Different techniques aimed at evaluating the readability of written texts have been widely used in medicine and pharmacy for more than two decades. Among other tools, the Gunning Fox Index (FOG index) is one of the most frequently applied in modern linguistics [5]. What should be emphasized here, in our opinion, readability is also important from an ethical point of view. Participants in clinical trials should provide informed consent before being introduced to a study or control group. Informed consent, however, is also the matter of language which is used between trialists and patients; the use of difficult language may limit a patient's ability to provide informed consent.

The presented study aimed at comparing Polish and English (United Kingdom) drug leaflets (patient-oriented documents) in terms of readability. Readability was investigated using the abovementioned FOG index. The selection of leaflets was based on convenient sampling. In each case, a different part of the leaflets was selected. Moreover, in terms of language variation, the analogous part of drug leaflets was used to achieve greater opportunities to compare the results. English texts were analysed using http://gunning-fogindex.com/; Polish by using http://www.jasnopis. pl. Jasnopis provides additional comments which were attached to the analysis (qualitative analysis). Results were presented in additional comments corresponding to United States of America grade level, and explanation obtained from the Jasnopis website. Three drug leaflets were selected: drugs containing i) metoprolol tartrate - in this case, warnings and precautions were analysed; ii) carvedilol - indications were analysed so as to evaluate readability, and iii) a fixed-dose combination (FDC) contains three active pharmaceutical ingredients (a combination of perindopril, indapamide, and amlodipine was selected) - 'how to take the drug' section was analysed.

Table 1 summarizes the findings revealed by our analysis. First of all, the overall value of the FOG index should be considered as relatively too

Address for correspondence: Damian Świeczkowski, BA, MPharm, PhD Candidate, First Department of Cardiology, Medical University of Gdansk, ul. Dębinki 7, 80-211, Gdańsk, Poland, tel: +58 34925 00; +58 3492504 , e-mail: damian.swieczkowski@gumed.edu.pl 
Table 1. Results of analysis.

\begin{tabular}{|c|c|c|}
\hline & Extract & Result and interpretation \\
\hline $1 \mathrm{a}$ & $\begin{array}{l}\text { Do not take Metoprolol Tartrate tablets if you. } \\
\text { Are allergic to metoprolol, other beta-blockers or any other } \\
\text { ingredients of this medicine (listed in section 6). } \\
\text { Suffer with heart conduction or rhythm problems. } \\
\text { Have severe or uncontrolled heart failure. } \\
\text { Are in shock caused by heart problems. } \\
\text { Suffer with blocked blood vessels, including blood circulation } \\
\text { problems (which may cause your fingers and toes to tingle } \\
\text { or turn pale or blue). } \\
\text { Have a slow heart rate or have suffered a heart attack which has } \\
\text { been complicated by a significantly slow heart rate. } \\
\text { Suffer from a tight, painful feeling in the chest in periods of rest } \\
\text { (Prinzmetal's angina). } \\
\text { Have or have had breathing difficulties or asthma including COPD } \\
\text { (chronic obstructive pulmonary disease). } \\
\text { Causing cough, wheezing or breathlessness, phlegm or an increase } \\
\text { in chest infections). } \\
\text { Suffer with untreated phaeochromocytoma (high blood pressure due } \\
\text { to a tumour near the kidney). } \\
\text { Suffer from increased acidity of the blood (metabolic acidosis). } \\
\text { Have low blood pressure. } \\
\text { Suffer with diabetes associated with frequent episodes of low blood } \\
\text { sugar (hypoglycaemia). } \\
\text { Have liver or kidney disease or failure. } \\
\text { Are given other medicines for blood pressure by injection especially } \\
\text { verapamil, diltiazem or disopyramide. }\end{array}$ & $\begin{array}{l}\text { The FOG index is: } 12.16(12) \\
\text { The number of words in extract: } \\
187 \text {. } \\
\text { The number of } 3+\text { syllable words: } \\
35 . \\
\text { High school senior. } \\
\text { Fairly simple language, understand- } \\
\text { able for high school students. }\end{array}$ \\
\hline $1 b$ & $\begin{array}{l}\text { Kiedy nie stosować leku Betaloc ZOK. } \\
\text { Jeśli pacjent ma uczulenie na metoprololu winian lub którykolwiek } \\
\text { z pozostałych składników tego leku (wymienionych w punkcie 6). } \\
\text { Jeśli pacjent ma uczulenie na inne leki blokujące receptory } \\
\beta \text {-adrenergiczne, np. atenolol, propranolol. } \\
\text { Jeśli u pacjenta występuje. } \\
\text { Wstrząs kardiogenny. } \\
\text { Zespół chorego węzła zatokowego (chyba że wszczepiony jest } \\
\text { rozrusznik serca). } \\
\text { Blok przedsionkowo-komorowy II lub III stopnia. } \\
\text { Niewyrównana niewydolność serca (duszność, obrzęk okolicy } \\
\text { kostek). } \\
\text { Bradykardia (zwolnienie rytmu serca poniżej } 45 \text { skurczów na minutę). } \\
\text { Bardzo niskie ciśnienie tętnicze, które może powodować omdlenie. } \\
\text { Ciężkie zaburzenia krążenia w tętnicach obwodowych. } \\
\text { Kwasica metaboliczna. } \\
\text { Nieleczony guz chromochłonny nadnerczy. } \\
\text { Podejrzenie świeżego zawału mięśnia sercowego, jeśli czynność serca } \\
\text { jest wolniejsza niż } 45 \text { skurczów na minutę, odstęp PO jest dłuższy } \\
\text { niż 0,24 s lub ciśnienie skurczowe jest mniejsze niż } 100 \text { mmHg. } \\
\text { Jeśli pacjentowi podawane są (krótko- lub długotrwale) leki o działaniu } \\
\text { inotropowym dodatnim, pobudzające receptory } \beta \text {-adrenergiczne. }\end{array}$ & $\begin{array}{l}\text { The FOG index is: } 11.94(12) \\
\text { The number of words in extract: } \\
131 . \\
\text { The number of } 4+\text { syllable words: } \\
17 . \\
\text { High school senior. } \\
\text { Fairly simple language, understand- } \\
\text { able for high school students. } \\
\text { Additional comments from } \\
\text { Jasnopis: } \\
\text { - the text should be considered as } \\
\text { difficult for average Polish user, } \\
\text { - significantly more difficult parts } \\
\text { of the text were highlighted } \\
\text { in bold font (typeface). }\end{array}$ \\
\hline $2 a$ & $\begin{array}{l}\text { Talk to your doctor or pharmacist before using Metoprolol Tartrate } \\
50 \text { mg tablets if you. } \\
\text { Have a history of allergic reactions, for example to insect stings, } \\
\text { foods or other substances. } \\
\text { Have diabetes mellitus (low blood sugar levels may be hidden by } \\
\text { this medicine). } \\
\text { Have controlled heart failure. } \\
\text { Have a slow heart rate or blood vessel disorder. } \\
\text { Suffer from treated phaeochromocytoma (high blood pressure } \\
\text { due to tumors near the kidney). } \\
\text { Have or have suffered from psoriasis (severe skin rashes). } \\
\text { Have liver cirrhosis. } \\
\text { Are elderly. } \\
\text { Have myasthenia gravis. } \\
\text { If you suffer from dry eyes. }\end{array}$ & $\begin{array}{l}\text { The FOG index is: } 9.33 \text { (9) } \\
\text { The number of words in extract: } \\
92 \text {. } \\
\text { The number of } 3+\text { syllable words: } \\
13 . \\
\text { High school freshman. } \\
\text { Simple language understandable for } \\
\text { junior high school pupils. }\end{array}$ \\
\hline
\end{tabular}


Table 1 (cont.). Results of analysis.

Extract

2b Przed rozpoczęciem stosowania leku Betaloc ZOK należy omówić to z lekarzem. Należy poinformować lekarza, jeśli u pacjenta występuje. Astma oskrzelowa, świszczący oddech lub inne, podobne zaburzenia oddychania albo reakcje alergiczne, np. na jad owadów, pokarm lub inne substancje. Jeśli u pacjenta kiedykolwiek wystąpił napad astmatyczny lub świszczący oddech — nie należy stosować tego leku bez konsultacji z lekarzem.

Ból w klatce piersiowej, spowodowany dławicą Prinzmetala.

Zaburzenia krążenia lub niewydolność serca.

Choroba wątroby.

Blok serca ${ }^{\circ}$ (zaburzenia przewodzenia w sercu).

Chromanie przestankowe (męczenie się i słabnięcie jednej lub obu nóg podczas chodzenia).

Cukrzyca (lekarz może zalecić zmianę dawek leków przeciwcukrzycowych).

Nadczynność tarczycy — lek Betaloc ZOK może maskować objawy.

Guz chromochłonny nadnerczy.

Łuszczyca.

3a Carvedilol belongs to a group of medicines called beta-blockers that work by relaxing and widening the blood vessels. This makes it easier for your heart to pump blood around the body and reduces blood pressure and strain on your heart.

Carvedilol is used:

For the treatment of high blood pressure (hypertension).

For the treatment of chest pain that occurs when the arteries that supply your heart with blood carrying oxygen are narrowed which results in less oxygen reaching your heart muscles (angina).

For the treatment of weakening of the heart muscle (heart failure), in combination with other medicines.

3b Lek Dilatrend w postaci tabletek o mocy $6,25 \mathrm{mg}, 12,5 \mathrm{mg}$ lub $25 \mathrm{mg}$ zawiera substancję czynną.

Karwedylol, którego działanie polega na rozszerzaniu naczyń krwionośnych poprzez blokowanie receptorów adrenergicznych typu alfa1 oraz hamowaniu aktywności układu renina-angiotensyna-aldosteron poprzez blokadę receptorów beta.

Lek Dilatrend wskazany jest w leczeniu.

Przewlekłej niewydolności serca (stabilnej postaci przewlekłej niewydolności serca o łagodnym, umiarkowanym i ciężkim nasileniu), jako uzupełnienie zazwyczaj stosowanego leczenia podstawowego.

Nadciśnienia tętniczego.

Stabilnej choroby wieńcowej.

Pacjentów po przebytym zawale mięśnia serca ze stwierdzonymi zaburzeniami czynności lewej komory (frakcja wyrzutowa lewej komory $($ LVEF $) \leq 40 \%)$.

4a Always take this medicine exactly as your doctor or pharmacist has told you.

Check with your doctor or pharmacist if you are not sure.

Swallow the tablet with a glass of water preferably in the morning and before a meal. Your doctor will decide on the correct dose for you.

This will normally be one tablet once a day.

If you take more Coverdine than you should.

Taking too many tablets may cause you blood pressure to become low or even dangerously low sometimes associated with nausea, vomiting, cramps, dizziness, sleepiness, mental confusion, oliguria (passing less urine than is normal), anuria (no production or passing of urine). You may feel lightheaded, faint, or weak. If blood pressure drop is severe enough shock can occur. Your skin could feel cool and clammy and you could lose consciousness. Seek immediate medical attention if you take too many Coverdine tablets.

If you forget to take Coverdine.
Result and interpretation

The FOG index is: 9.68 (10)

The number of words in extract:

87.

The number of $4+$ syllable words:

4.

High school sophomore.

Simple language understandable for high school pupils.

Additional comments from Jasnopis:

- the text should be considered as difficult for average Polish user,

- significantly more difficult parts of the text were highlighted in bold font (typeface).

The FOG index is: $11.43(11)$

The number of words in extract: 98.

The number of $3+$ syllable words: 12.

High school junior.

Simple language understandable for high school pupils.

The FOG index is: 13.43 (13)

The number of words in extract: 81.

The number of $4+$ syllable words: 8.

College freshman.

A language quite difficult, understandable for undergraduate students.

Additional comments from Jasnopis: - very complicated and professional text, understanding of which may require specialist knowledge, - significantly more difficult parts of the text were highlighted in bold font (typeface).

The FOG index is: 11.97 (12)

The number of words in extract: 243.

The number of $3+$ syllable words: 38.

High school senior. 
Table 1 (cont.). Results of analysis.

\begin{tabular}{|c|c|c|}
\hline & Extract & Result and interpretation \\
\hline & \multicolumn{2}{|l|}{$\begin{array}{l}\text { It is important to take your medicine every day as regular treatment } \\
\text { is more effective. However, if you forget to take a dose of Coverdine, } \\
\text { take the next dose at the usual time. Do not take a double dose to } \\
\text { make up for a forgotten dose. } \\
\text { If you stop taking Coverdine. } \\
\text { As the treatment for high blood pressure is usually life-long, you } \\
\text { should discuss with your doctor before stopping this medicinal } \\
\text { product. } \\
\text { If you have any further questions on the use of this medicine, } \\
\text { ask your doctor, pharmacist or nurse. }\end{array}$} \\
\hline $4 b$ & $\begin{array}{l}\text { Ten lek należy zawsze stosować zgodnie z zaleceniami lekarza lub } \\
\text { farmaceuty. W razie wątpliwości należy zwrócić się do lekarza lub far- } \\
\text { maceuty. Tabletkę należy połknąć, popijając szklanką wody, najlepiej } \\
\text { rano, przed posiłkiem. Lekarz określi odpowiednią dawkę dla pacjenta. } \\
\text { Zazwyczaj zalecana dawka to jedna tabletka raz na dobę. } \\
\text { Zastosowanie większej niż zalecana dawki leku Triplixam. } \\
\text { Zażycie zbyt wielu tabletek może spowodować, że ciśnienie tętnicze } \\
\text { obniży się, nawet w niebezpiecznym stopniu, czemu czasami mogą } \\
\text { towarzyszyć nudności, wymioty, kurcze, zawroty głowy, senność, } \\
\text { dezorientacja, skąpomocz (wydalanie mniejszej ilości moczu niż } \\
\text { zwykle), bezmocz (brak wytwarzania lub wydalania moczu). Pacjent } \\
\text { może odczuwać „pustkę" w głowie, może wystąpić uczucie omdle- } \\
\text { wania lub słabnięcia. Jeśli obniżenie ciśnienia tętniczego jest znaczne, } \\
\text { może wystąpić wstrząs, w przypadku którego skóra staje się chłodna } \\
\text { i wilgotna, a pacjent może stracić przytomność. W razie zażycia zbyt } \\
\text { wielu tabletek leku Triplixam należy niezwłocznie skontaktować się } \\
\text { z lekarzem lub zgłosić się do oddziału pomocy doraźnej najbliższego } \\
\text { szpitala. } \\
\text { Pominięcie przyjęcia leku Triplixam. } \\
\text { Ważne jest, aby przyjmować lek codziennie, ponieważ regularne sto- } \\
\text { sowanie zapewnia skuteczniejsze działanie. Jeśli jednak pominie się } \\
\text { dawkę leku Triplixam, następną dawkę należy przyjąć o zwykłej porze. } \\
\text { Nie należy stosować dawki podwójnej w celu uzupełnienia pominiętej } \\
\text { dawki. } \\
\text { Przerwanie stosowania leku Triplixam. } \\
\text { Leczenie wysokiego ciśnienia tętniczego jest zwykle długotrwałe, dla- } \\
\text { tego przed przerwaniem przyjmowania tego leku należy skontaktować } \\
\text { się z lekarzem. W razie jakichkolwiek dalszych wątpliwości związanych } \\
\text { ze stosowaniem tego leku należy zwrócić się do lekarza, farmaceuty } \\
\text { lub pielęgniarki. }\end{array}$ & $\begin{array}{l}\text { The FOG index is: } 13.01(13) \\
\text { The number of words in extract: } \\
230 \text {. } \\
\text { The number of } 4+\text { syllable words: } \\
6 \text {. } \\
\text { College freshman. } \\
\text { A language quite difficult, under- } \\
\text { standable for undergraduate stu- } \\
\text { dents. }\end{array}$ \\
\hline
\end{tabular}

Sources of extracts: $1 \mathrm{a}$ - English version - metoprolol - precautions; $1 \mathrm{~b}$ - Polish version - metoprolol - precautions; $2 \mathrm{a}-$ English version - metoprolol - warnings; $2 b$ - Polish version - metoprolol - warnings; $3 a$ - English version - carvedilol - indication(s); $\mathrm{3b}$ - Polish version - carvedilol - indication(s); $4 \mathrm{a}$ - English version - fixed-dose combination - how to take the drug/use of drug; $4 \mathrm{~b}$ - Polish version - fixed-dose combination - how to take the drug/use of drug

high and varies from the language understood by junior high school pupils (metoprolol, English leaflet) to language which is comprehended by undergraduate students (FDC, Polish leaflet). Taking into consideration that a relatively significant part of society may not achieve these levels of education, the language used in drug leaflets, at least those under evaluation, seem to be too difficult. Moreover, the present findings significantly exceed the readability guidelines authorized by the $\mathrm{Na}-$ tional Institutes of Health and the American Medical Association, which strongly recommend that these kinds of documents should not be written at greater than a sixth-grade reading level (lower intermediate level) [6]. Since overall capacity for understanding medical information deteriorates with aging, and the use of drugs is more frequent among the elderly, current findings revealed that the situation seems to be even worse than it would have, resulting from a simple analysis of the association between the complexity of language and level of education. Moreover, the number of complex words, though defined differently in Polish and English, varies from 4 to 38; still, this number might be considered too high, and the language requires substantial simplification. Although the aim of this paper is not qualitative, some qualitative aspects should be mentioned, at least briefly. 
Polish drug leaflets contain some highly specialized vocabulary, which is understood only by people with a medical background. Among other examples, it is worth citing the following expressions: 'blok przedsionkowo-komorowy II lub III stopnia, wstrzas kardiogenny, niewyrównana niewydolność serca' (as it was used in the analyzed material). Hopefully, in the last example, the drug leaflet contains symptoms of unstable heart failure, which may be helpful for patients to correctly recognize their condition. 'Guz chromochtonny nadnerczy' is a term recognized in both language versions; however, in the English one, an easier descriptive form was added: 'high blood pressure due to a tumor near the kidney'. This explanation does not denote an explanation of the disease, rather is focused on the most important and life-threatening symptoms of the tumor, particularly important from the perspective of drug-disease interaction. This approach is also identified in the case of a more common disease (psoriasis); symptoms of this condition were described in the English version. Finally, the Polish sentences are significantly longer than English, which can be seen in this example: 'podejrzenie świeżego zawatu mieśnia sercowego, jeśli czynność serca jest wolniejsza niz 45 skurczów na minute, odstęp $P Q$ jest dtuższy niz 0,24 s lub ciśnienie skurczowe jest mniejsze niz $100 \mathrm{mmHg}$ ' (as it was used in the analyzed material). This sentence contains highly precise values, which are difficult for patients to interpret.

Numerous studies have revealed that patient-oriented documents contain difficult language which may be an important problem for patients. Huang et al. [7] revealed that ophthalmologic online patient education materials are written in the style highly above that recommended by experts; in terms of the FOG index, authors estimated it in the range from 12.4 to 18.4 , which is even higher than noticed in this study. A level higher than recommended was also observed in a similar study aimed at evaluating the readability of online patient information for vestibular schwannoma [5]. Also, materials for pregnant women are provided above recommendations, and only $0.5 \%$ of materials analyzed by Storr et al. [8] were written below grade six. Even documents provided by the medical association need substantial improvement in terms of readability as it was depicted by Betschart et al. [9], who highlighted some improvements in quality of documents prepared by European Association of Urology; however, much more effort should be paid in order to achieve acceptable transparency.

Although the value of the FOG index of both analyzed language variation is comparable, the qualitative analysis revealed that the Polish language version seems to be more difficult for patients, due to the significant number of highly-specialized vocabulary, length of sentences, and lack of easy explanations of some medical terms. Nevertheless, a more advanced analysis should be performed to provide further more valid evidence, e.g. different kinds of research tools may add new relevant findings. It is worth remembering that the present study is exploratory.

\section{Conflict of interest: None declared}

\section{References}

1. Aronson L. Medical linguistics. J Gen Intern Med. 2007; 22(12): 1781, doi: 10.1007/s11606-007-0314-1, indexed in Pubmed: 17924173.

2. Bittner A, Jonietz A, Bittner J, et al. Translating medical documents into plain language enhances communication skills in medical students--A pilot study. Patient Educ Couns. 2015; 98(9): 1137-1141, doi: 10.1016/j.pec.2015.05.024, indexed in Pubmed: 26095344.

3. Pires C, Vigário M, Cavaco A. Readability of medicinal package leaflets: a systematic review. Rev Saude Publica. 2015; 49: 4, doi: 10.1590/s0034-8910.2015049005559, indexed in Pubmed: 25741660.

4. Swieczkowski D, Mogielnicki M, Cwalina N, et al. Medication adherence in patients after percutaneous coronary intervention due to acute myocardial infarction: From research to clinical implications. Cardiol J. 2016; 23(5): 483-490, doi: 10.5603/ CJ.a2016.0048, indexed in Pubmed: 27439366.

5. Spiers H, Amin N, Lakhani R, et al. Assessing readability and reliability of online patient information regarding vestibular schwannoma. Otol Neurotol. 2017; 38(10): e470-e475, doi: 10.1097/ MAO.0000000000001565, indexed in Pubmed: 28885483.

6. Weiss BD. Health literacy and patient safety: help patients understand. Manual for clinicians. 2nd ed. American Medical Association, American Medical Foundation, Chicago (IL) 2007.

7. Huang G, Fang $\mathrm{CH}$, Agarwal N, et al. Assessment of online patient education materials from major ophthalmologic associations. JAMA Ophthalmol. 2015; 133(4): 449-454, doi: 10.1001/ jamaophthalmol.2014.6104, indexed in Pubmed: 25654639.

8. Storr T, Maher J, Swanepoel E. Online nutrition information for pregnant women: a content analysis. Matern Child Nutr. 2017; 13(2), doi: 10.1111/mcn.12315, indexed in Pubmed: 27353248.

9. Betschart P, Zumstein V, Bentivoglio M, et al. Readability assessment of online patient education materials provided by the European Association of Urology. Int Urol Nephrol. 2017; 49(12): 2111-2117, doi: 10.1007/s11255-017-1695-7, indexed in Pubmed: 28905177. 